\title{
Reversal of pulmonary arterial hypertension and neointimal formation by kinin $\mathrm{B} 1$ receptor blockade
}

\author{
Dileep Reddy Rampa', Priya Murugesan ${ }^{1}$, Honglu Chao ${ }^{2}$, Huiying Feng ${ }^{1,4}$, Wenxin Dai ${ }^{1}$, Dongwon Lee ${ }^{1}$, \\ Anton Pekcec ${ }^{3}$, Henri Doods ${ }^{3}$ and Dongmei $\mathrm{Wu}^{1,4^{*}}$ (1)
}

\begin{abstract}
Background: This study examined whether Bl113823, a novel selective kinin B1 receptor antagonist can reverse established pulmonary arterial hypertension (PAH), prevent right heart failure and death, which is critical for clinical translation.

Methods: Left pneumonectomized male Wistar rats were injected with monocrotaline to induce PAH. Three weeks later, when PAH was well established, the rats received daily treatment of Bl113823 or vehicle for 3 weeks.

Results: Treatment with BI113823 from day 21 to day 42 after monocrotaline injection reversed established PAH as shown by normalized values of mean pulmonary arterial pressure (mPAP). BI113823 therapy reversed pulmonary vascular remodeling, pulmonary arterial neointimal formation, and heart and lung fibrosis, reduced right ventricular pressure, right heart hypertrophy, improved cardiac output, and prevented right heart failure and death. Treatment with BI113823 reduced TNF-a and IL-1 $\beta$, and macrophages recruitment in bronchoalveolar lavage, reduced CD-68 positive macrophages and expression of proliferating cell nuclear antigen (PCNA) in the perivascular areas, and reduced expression of iNOS, B1 receptors, matrix metalloproteinase (MMP)-2 and MMP-9 proteins, and the phosphorylation of ERK1/2 and AKT in lung. Treatment with B1113823 reduced mRNA expression of ANP, BNP, BMHC, CGTF, collange-I and IV in right heart, compared to vehicle treated controls. In human monocytes cultures, BI113823 reduced LPS-induced TNF-a production, MMP-2 and MMP-9 expression, and reduced TNF-a-induced monocyte migration.
\end{abstract}

Conclusions: We conclude that BI1 13823 reverses preexisting severe experimental pulmonary hypertension via inhibition of macrophage infiltration, cytokine production, as well as down regulation of matrix metalloproteinase proteins.

Keywords: Inflammation, Macrophage, Neointimal formation, Pulmonary arterial remodeling, Right heart hypertrophy

\section{Background}

Pulmonary arterial hypertension (PAH) pathobiology involves pulmonary arterial remodeling, vasoconstriction and in situ thrombosis, leading to enhanced pulmonary

\footnotetext{
*Correspondence: dongmeiwu18@gmail.com

${ }^{1}$ Department of Bio-Nanotechnology and Bio-Convergence Engineering, Chonbuk National University, Jeonju, South Korea
}

Full list of author information is available at the end of the article vascular resistance and pressure, to right heart failure and death [1-3]. Inflammation is a prominent pathologic feature in PAH [2-7]. Infiltration of inflammatory cells, including macrophages, are found in pulmonary perivascular spaces and around the plexiform lesions in lung biopsies from patients with $\mathrm{PAH}[6,7]$. Proinflammatory mediators, such as TNF- $\alpha$, IL- $1 \beta$, and IL- 6 are elevated in the serum of patients with $\mathrm{PAH}$ and can predict original author(s) and the source, provide a link to the Creative Commons licence, and indicate if changes were made. The images or other third party material in this article are included in the article's Creative Commons licence, unless indicated otherwise in a credit line to the material. If material is not included in the article's Creative Commons licence and your intended use is not permitted by statutory regulation or exceeds the permitted use, you will need to obtain permission directly from the copyright holder. To view a copy of this licence, visit http://creativecommons.org/licenses/by/4.0/. The Creative Commons Public Domain Dedication waiver (http://creativeco mmons.org/publicdomain/zero/1.0/) applies to the data made available in this article, unless otherwise stated in a credit line to the data. 
the survival of patients with idiopathic PAH [2, 3, 5-7]. Therefore, a better understanding of inflammatory pathways and their role in the pathogenesis of PAH may lead to targeted therapeutic approaches [2-7].

Kinin B1 receptors are involved in a variety of pathological processes of inflammation [8-13]. Kinins are proinflammatory peptides that exert a variety of biological actions via activation of two receptor subtypes, B1 and B2 $[8,9]$. Kinin B1 receptors are normally weakly expressed, but are strongly upregulated following injury or exposure to pro-inflammatory agents such as cytokines and endotoxins, while the B2 receptors are expressed constitutively $[8,9]$. Kinin B2 receptors activation is thought to mediate most of the beneficial cardiovascular effects of kinins, as well as the beneficial effects of angiotensin 1 converting enzyme inhibitors $[8,9]$. In contrast, kinin B1 receptors are involved in diverse pathological processes including inflammation, platelet activation, smooth muscle contraction, increased vascular permeability, edema, pain, cytokine and chemokine release, cell proliferation, and tissue remodeling [8-13], responses that are key components of PAH.

We have identified that kinin B1 receptors play important roles in the pathogenesis of $\mathrm{PAH}$ and vascular remodeling [14]. Kinin B1 receptor expression is increased in an experimental model of PAH in rats [14], as well as on foamy macrophages within thickened intimal plaques in patients with atheromatous disease [15]. It is important to note that unlike B2 receptors, kinin B1 receptors are not rapidly internalized and desensitized $[10,16]$. Thus kinin B1 receptor-induced responses are more persistent and could contribute to long term pathological changes such as those seen in PAH $[10,16]$. Therefore, kinin B1 receptors could represent a novel therapeutic target in chronic inflammatory processes leading to these events $[10,16]$. We have shown that early treatment with a selective kinin B1 receptor antagonist BI113823 reduced lung inflammation, prevented the development of PAH and vascular remodeling [14]. $\mathrm{PAH}$ is often not recognized until the disease is relatively advanced [1]. Therefore, finding a drug that is effective when administered after established PAH would be of major significance. The present study was designed to examine whether treatment with a small molecule orallyactive, non-peptide B1 receptor antagonist BI113823 can rescue preexisting PAH and vascular remodeling, and prevent right heart failure and death in rats. The selection of animal models is also critical to the discovering novel agents for the treatment of PAH. The present study utilized a two "hits" pneumonectomy plus monocrotaline induced PAH model which shows histological evidence of inflammation, and develops severe pulmonary hypertension and vascular remodeling $[17,18]$. This model has also been used by many investigators to test new drug treatments on attenuating the development of $\mathrm{PH}$, reversing established disease or promoting survival [14, 17-19]. The cellular mechanisms underlying the protection afforded by kinin $\mathrm{B} 1$ receptor inhibition were also examined in animals and in human monocytic cells.

\section{Materials and methods}

These animal studies were approved by the Institutional Animal Care and Use Committee at Chonbuk National University, and the National Institutes of Health (NIH) Guide for the Care and Use of Laboratory Animals. A total of 55 male, 10-week-old Wistar rats, weighing between 250 and $300 \mathrm{~g}$ were studied.

\section{MCT-induced pulmonary hypertension in left pneumonectomized rats}

Experimental model of PAH and vascular remodeling was induced by monocrotaline-challenge in left pneumonectomized rats as previously described [14]. Briefly, the rats were anesthetized with intramuscular injections of ketamine $\left(80 \mathrm{mg} \mathrm{kg}^{-1}\right)$ and xylazine $(10 \mathrm{mg} \mathrm{kg}-1$ ) before undergoing left pneumonectomy. On week later, rats were injected subcutaneously in the right hind limb with monocrotaline (MCT) $(60 \mathrm{mg} / \mathrm{kg}$, WAKO, Japan). Three weeks after MCT injection, these rats were then randomly assigned to receive treatment with vehicle (0.5\% Natrosol $+0.01 \%$ TWEEN 80, p.o., b.i.d., $\mathrm{n}=8)$, or with BI113823 (selective B1 receptor antagonist, $30 \mathrm{mg} /$ $\mathrm{kg}$, p.o., b.i.d., $\mathrm{n}=8$ ) for 3 weeks. Additional six animals was used to confirm the development of severe PAH and vascular remodeling at 3 weeks after MCT injection.

At the end of experiment, rats were anesthetized before a pulmonary arterial catheter was inserted through the right internal jugular vein. The right atrial pressure, right ventricular systolic blood pressure (RVSP), and pulmonary arterial pressure (PAP) were recorded using a Powerlab data acquisition system (ADInstruments Inc., CO). Next, another 2F miniaturized combined conductance catheter-micromanometer (Model SPR-838, Millar instruments, Houston, TX) was inserted into the carotid artery to obtain the arterial pressure. Then, this catheter-micro-manometer was advanced into the left ventricle to record the left ventricular pressure and its first derivative ( $\pm \mathrm{dp} / \mathrm{dp}$ max).

Bronchoalveolar lavage (BAL) was collected through a 14-gauge angiocatheter. Lavages were collected twice after $2.5 \mathrm{ml}$ of sterile PBS was infused into the rat's lung. A standard hemocytometer was used for BAL cell counting. Differential cell counts were performed on Giemsa-wright stained (Microscopy Hemacolor-Merck; Germany) cytospin preparations. Lung and heart tissues were collected and weighed. Liquid nitrogen was used to snap freeze one set of the tissues, while other tissues sets were fixed in 
buffered formalin for histopathological examination. The BAL protein concentration was determined using a Smart BCA Assay Kit (Intron Biotechnology Inc. South Korea). Enzyme immunoassay kits for rat interleukin 1-beta (IL$1 \beta)$ (R \& D Systems, Minneapolis, MN) and tumor necrosis factor (TNF)- $\alpha$ (BioLegend, San Diego, CA) were used to determine the concentrations of these mediators in BAL fluid and plasma. Neutrophil accumulation in the lung was measured by determining myeloperoxidase (MPO) activity as previously described [13].

\section{Histological analysis}

As previously described [14], standard histopathological procedures were used to prepare 5 - $\mu \mathrm{m}$-thick sections. The sections were deparaffinized and stained with hematoxylin and eosin (Sigma, St. Louis, MO, USA), elastic van gieson (EVG, Sigma) and with Masson-Trichrome (American Master Tech Scientific, Inc. Lodi, CA, USA). The lungs were examined with light microscopy for morphological alterations. All of the analysis was blinded. Parameters of vascular remodeling were performed using Image $J$ software. The pulmonary arterial medial wall thickness was calculated as $\%$ wall thickness $=($ wall thickness $\times 2$ /external diameter) $\times 100$. The severity of neointimal formation was scored according to methods previously described [17]. In this scoring system: $0=$ the absence of neointimal lesion; $1=$ less than $50 \%$ luminal occlusion; $2=$ greater than $50 \%$ luminal occlusion. The average score of 50 vessels was obtained for each animal.

\section{Immunohistochemical analysis}

For IHC analysis, 5- $\mu$ m-lung sections were deparaffinized, hydrated and incubated in $10 \mathrm{mM}$ sodium citrate buffer at $99^{\circ} \mathrm{C}$ for $20 \mathrm{~min}$ for antigen retrieval. Sections were incubated overnight with a primary antibody to one of the following antigens: kinin $\mathrm{B} 1$ receptor, kinin $\mathrm{B} 2$ receptor, iNOS, CD68, proliferating cell nuclear antigen (PCNA), matrix metalloproteinase (MMP)-9 (all from Santa Cruz Biotechnology, Santa Cruz, CA), MMP-2 (Aviva systems biology, San Diego, CA), $\alpha$-smooth muscle actin ( $\alpha$-SMA, Abcam, Cambridge, MA). Next, the section was incubated for $1 \mathrm{~h}$ with FITC-labeled goat anti-rabbit IgG secondary antibody (Santa Cruz Biotechnology) or Alexa Fluor goat anti-rabbit IgG H \&C secondary antibody. Sections were counterstained with Ultra Cruz Mounting Medium with 4',6-diamidino2-phenylindole (DAPI; sc-24941, Santa Cruz Biotechnology) and cover slipped. Fluorescent images were taken using the Nikon Eclipse TE2000-U fluorescence microscope (Nikon Corp., Tokyo, Japan) and a Nikon LWD 0.52 digital camera. Fluorescent intensity was quantified using Image J software.
Reverse-transcription polymerase chain reaction (RT-PCR) RT-PCR for transcript levels of kinin B1 receptors in lung and right heart, and atrial natriuretic peptide (ANP), brain natriuretic peptide (BNP), beta myosin heavy chain $(\beta M H C)$ connective tissue growth factor (CTGF), Collagen I and IV were measured in rat right ventricle as previously described $[14,20]$.

\section{Western blot}

Western blot experiments were performed to determine protein expression of extracellular signal regulated protein kinase (ERK1/2), phospho-ERK1/2, AKT and phospho-AKT in lung tissues as previously described [21]. Briefly, the lung protein extracts were separated by using SDS-PAGE and transferred to nitrocellulose membranes. The blots were incubated with primary antibodies against ERK1/2, phospho-ERK1/2, Akt, phospho-AKT and $\beta$-actin (all from Santa Cruz Biotechnology, Santa Cruz, CA), followed by incubation with HRP-conjugated secondary antibody. Immunoreactivity was detected using an enhanced chemiluminescence Western blotting detection kit (Amersham, Piscataway, NJ). Results were quantified using Image J software.

\section{Survival study}

Additional groups of animals were used to evaluate the effect of BI113823 on long-term survival following monocrotaline-induced PAH in left pneumonectomized rats. Animal preparation was the same as described above for the first series of experiments. Three weeks after the administration of monocrotaline, animals received daily treatments of vehicle or BI113823 $\left(30 \mathrm{mg} \mathrm{kg}{ }^{-1}\right.$, p.o., b.i.d.). This experiment was terminated 6 months after monocrotaline injection.

\section{Human monocyte assay \\ Cell culture and treatment}

U937 human monocytic cells (ATCC, Manassas, VA) were grown in RPMI 1640 supplemented with $10 \%$ FBS. Cells $\left(1 \times 10^{6}\right.$ cells/well $)$ were seeded in 24 -well plates in serum free-RPMI medium and were treated with LPS $(100 \mathrm{ng} / \mathrm{ml})$ in the presence or absence of kinin B1 receptor antagonist BI113823 (0.001, 0.01, 0.1, $1 \mu \mathrm{M})$. Culture medium were collected at $24 \mathrm{~h}$ and stored in aliquots at $-80{ }^{\circ} \mathrm{C}$ for biochemical assays. Levels of tumor necrosis factor (TNF)- $\alpha$ (PeproTech, Rocky Hill, NJ, USA), and IL-1 $\beta$ (R\&D Systems, Minneapolis, MN, USA) in the culture medium were determined by using enzyme immunoassay kits according to the manufacturer's instructions. Immunohistochemical analysis for kinin B1 receptor, MMP-2 and MMP-9 expression in human macrophages was measured as described above. 


\section{Cell migration assay}

U937 human monocytes were treated with TNF- $\alpha$ $(25 \mathrm{ng} / \mathrm{ml})$ in the presence or absence of kinin B1 receptor antagonist BI113823 (0.001, 0.01, 0.1, $1 \mu \mathrm{M}) .1 \times 10^{6}$ treated cells (in $0.5 \mathrm{ml}$ serum free-RPMI medium) were added to each upper chamber of transmigration plate (\#140654, Thermo Scientific, Waltham, MA, USA) and $1.5 \mathrm{ml}$ of serum free-RMPI media containing the same concentrations of TNF- $\alpha$ and the BI113823 in upper chambers were added to lower chambers. Cells were incubated at $37^{\circ} \mathrm{C}$ and $5 \% \mathrm{CO}_{2}$ for $24 \mathrm{~h}$. After $24 \mathrm{~h}$ incubation, cells transmigrated to lower chambers were collected and counted using hemocytometer.

\section{Statistical analysis}

All data are reported as means \pm SEM. Statistical differences were determined by analysis of variance for repeated measures followed by Bonferroni's post hoc test using GraphPad Prism 5. P values $<0.05$ were considered statistically significant differences.

\section{Results \\ Reversal of the progression of PAH and prolong of long term survival}

Severe PAH, vascular remodeling and right heart hypertrophy was present at 3 weeks after MCT injection in left pneumonectomized rats [14]. Late treatment with BI113823 reversed the progression of pulmonary arterial hypertension, prevented the transition from PAH to right heart failure and prolonged long term survival. Arterial blood pressure was not significantly different among all study groups. BI113823 therapy reduced PAP ( $\downarrow$ by $50 \%$ ), RVP $(\downarrow$ by $41 \%)$, and $\mathrm{RV} /(\mathrm{LV}+\mathrm{S})$ ratio (0.62 in BI113823 group vs. 0.41 in vehicle group), and improved CI ( $\uparrow$ by $42 \%$ ) compared to vehicle treated animals (Fig. 1A-E, G). Furthermore, PAH led to the death of $69 \%(9 / 13)$ in the vehicle-treated animals, compared to $13 \%(1 / 8)$ in BI113823-treated animals at 6 months after MCT injection in left pneumonectomized rats (Fig. 1F). The mRNA expression of kinin B1 receptor in lung and right heart was marked upregulated in lung and right heart in vehicle treated PAH rats, and was reduced in rats treated with BI113823 (Fig. 2A, B). The mRNA expression of ANP, $\mathrm{BNP}$ and $\beta-\mathrm{MHC}$ in right heart was reduced in BI113823 treated rats compared to vehicle control (Fig. 2C-E).

\section{Reversal of the progression of tissue fibrosis and pulmonary vascular remodeling}

BI113823 therapy also reversed the adverse changes in the lung and heart remodeling (Fig. 3A). BI113823 treated animals had a significant decrease in medial wall thickness ( $\downarrow$ by $41 \%$ vs. vehicle control) and in vascular occlusion scores (Grade I and II occlusion: 29\% and 25\% vs. $9 \%$ and $81 \%$ in vehicle control) (Fig. 3B, C). Furthermore, BI113823 therapy also prevented the progression of fibrosis in lung and right heart (Fig. 4A-D) and the mRNA expression of CTGF, collagen I and IV was significantly reduced in BI113823 treated rats compared to vehicle treated rats (Fig. 4E-G).

\section{Reduction of inflammatory cell infiltration and cytokine production}

Macrophage cell recruitment is a key feature in the development of pulmonary artery hypertension $[4,14]$. Consistent with previous findings, bronchoalveolar lavage samples from MCT-challenged animals showed that macrophages are the majority of inflammatory cell influx at 3 weeks after MCT challenge. However, at 6 weeks following MCT-challenge, in addition to macrophage influx, there was also an increase in the number of neutrophils influx in the airway. In contrast, in rats treated with BI113823, the number of macrophages and neutrophils in BAL were reduced by $48 \%$ and $80 \%$ compared to the vehicle-control animals, respectively (Fig. 5A). Furthermore, BAL protein content, levels of IL-1 $\beta$, and TNF- $\alpha$ in lavage or plasma, and lung MPO activity were significantly lower in rats treated with BI113823 compared to vehicle controls (Fig. 5B-F). In addition, in vehicle-treated, MCT-injured lung tissues, there was marked recruitment of CD-68 positive macrophages into perivascular areas (Fig. 5G). There was also substantial vascular cell proliferation in the thickened media layer of the PA, as evidenced by a marked increase of PCNApositive cells in vehicle-treated animals (Fig. 5G). In contrast, treatment with BI113823 significantly reduced the perivascular macrophage accumulation and vascular cell proliferation (Fig. 5G).

\section{Signaling pathways in lung}

Kinin B2 receptors were expressed constitutively in rat lung (Fig. 6A). There was no significant difference of B2 receptor expression among study groups (Fig. 6A). Kinin B1 receptors were weakly expressed in rat lung in control animals, but were markedly upregulated in vehicle-treated MCT-injured lung tissues (Fig. 6A). In contrast, B1 receptor expression was significantly reduced in animals treated with BI113823 (Fig. 6A). These findings confirm that kinin B1 receptors play an important role in the pathogenesis and progression of pulmonary hypertension. Furthermore, tunnel positive cells, protein levels of inducible nitric oxide synthase (iNOS), MMP-2 and MMP-9 were also greatly increased in vehicle-treated MCT-injured lung tissues. Treatment with BI13823 significantly decreased tunnel positive cells and the expression of iNOS, MMP-2 and MMP-9 (Fig. 6B, C). In addition, we measured the AKT, ERK1/2, MMP-2 and MMP-9 expression and phosphorylation in lung tissues 


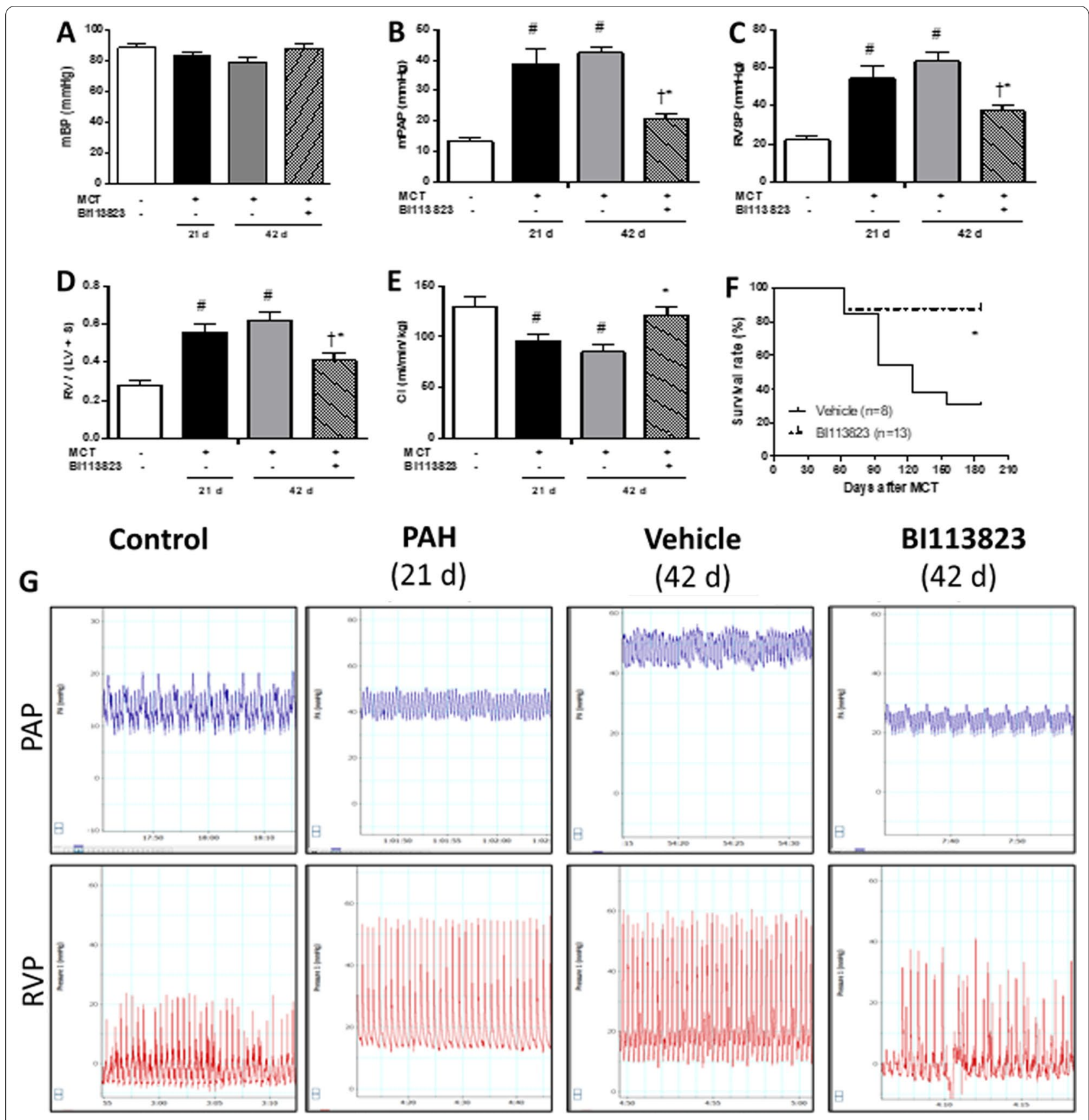

Fig. 1 Bl113823 reverses the pulmonary arterial hypertension. Measurement of $\mathbf{A}$ mean blood pressure (mBP), B mean pulmonary arterial pressure (mPAP), C right ventricular systolic pressure (RVSP), D ratio of right ventricular weight to left ventricular plus septum weight [RV/(LV + S)], and E cardiac index $(C l)$ in sham control group rats $(n=8)$, PAH-W3 group rats (pneumonectomized rats at 3 weeks after receiving monocrotaline) $(n=8)$, vehicle group rats (pneumonectomized rats received monocrotaline and vehicle treatment) $(n=8)$, and BI1 13823 group rats ( 3 weeks of treatment with selective kinin B1 receptor antagonist Bl1 $13823(30 \mathrm{mg} / \mathrm{kg}$, p.o., b.i.d.) starting from 3 weeks after monocrotaline injection in pneumonectomized rats) $(n=8)$. All values are expressed as mean \pm SEM, $n=6-8$. ${ }^{*} p<0.05$ vs. sham control; ${ }^{\dagger} p<0.05$ vs. control $(D 21) ;{ }^{*} p<0.05$ vs. vehicle. $\mathbf{F}$ Survival rates 6 months following administration of monocrotaline in pneumonectomized rats treated with vehicle vs. Bl113823. ${ }^{*} p<0.05$ versus the vehicle group. $\mathbf{G}$ Sample tracing of pulmonary arterial pressure and right ventricular pressure from rats

by Western blotting (Fig. 7A-G). No significant difference in AKT and total ERK1/2 expression was observed among study groups. However, there were significant increases in
AKT and ERK1/2 phosphorylation in vehicle-treated MCTinjured lung tissues. Treatment with BI113823 significantly reduced AKT \& ERK1/2 phosphorylation and MMP-2 \& 

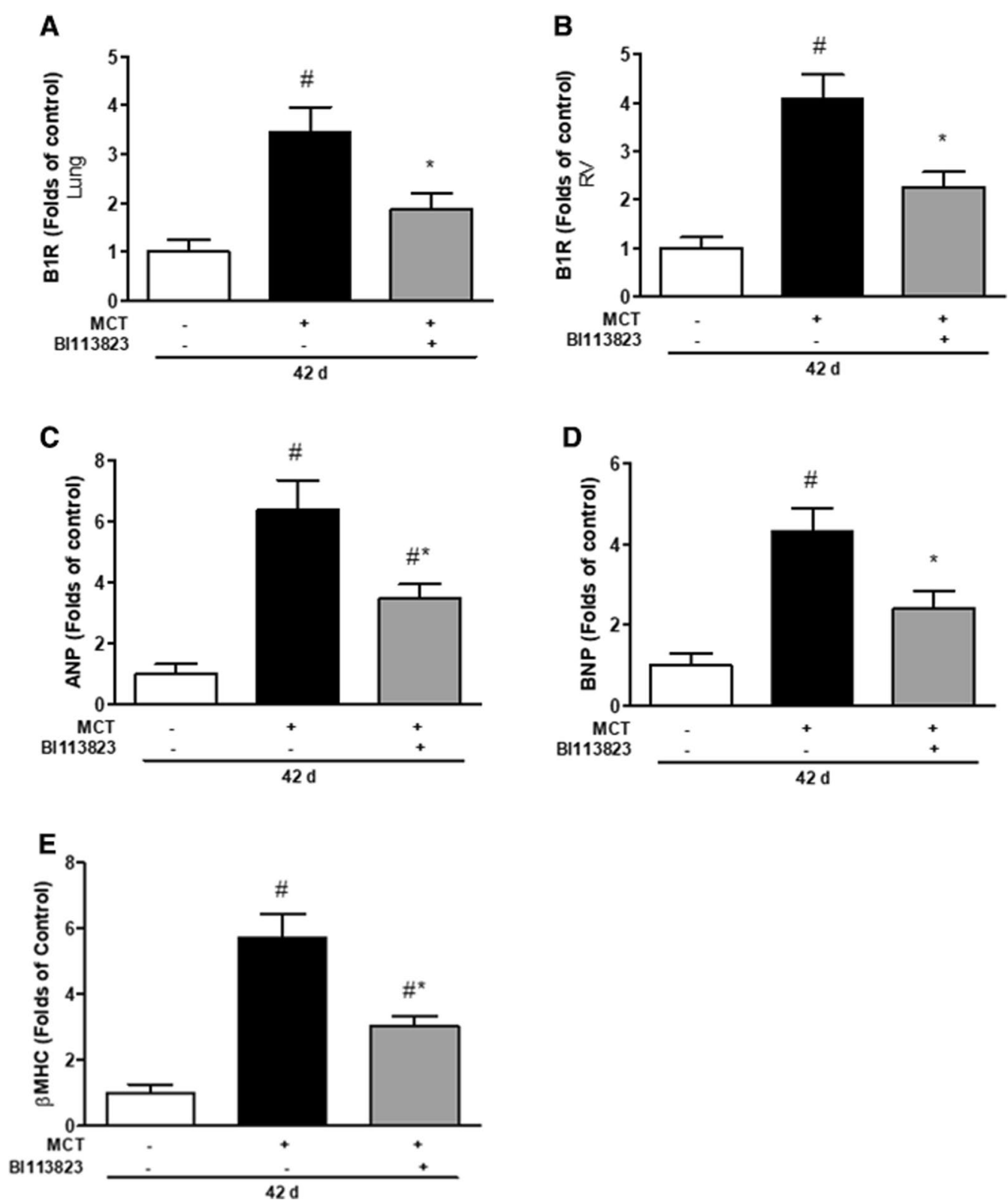

Fig. 2 Bl113823 attenuates cardiac expression of mediators. Expression of A B1R (in lung), B B1R, C ANP, D BNP, E BMHC mRNA in rat right ventricles at 42 days after $M C T$ injection. All values are expressed as mean $\pm S E M, n=6 .{ }^{*} p<0.05$ vs. sham control; ${ }^{*} p<0.05$ vs. vehicle

MMP-9 expression compared to vehicle-treated controls (Fig. 7A-G).

\section{Reduction of TNF-a production, MMPs expression and cell} migration in human monocytes

Macrophage recruitment is highly implicated in the pathogenesis of PAH $[6,7]$. We determined the effects of kinin B1 receptor mediated inflammatory responses in human monocytes. Treatment with BI113823 (1 nM to $1 \mu \mathrm{M})$ significantly reduced LPS-induced production of TNF- $\alpha$ and IL-1 $\beta$, and inhibited TNF- $\alpha$ induced monocyte migration (Fig. 8A-C). Furthermore, LPSinduced increase in the expression of kinin $\mathrm{B} 1$ receptors, MMP-2 and MMP-9 were inhibited by the treatment with BI113823 (Fig. 8D-G).

\section{Discussion}

The present study demonstrates that kinin B1 receptor blockade with BI113823 reverses pre-existing pulmonary arterial hypertension, cardiovascular remodeling, 


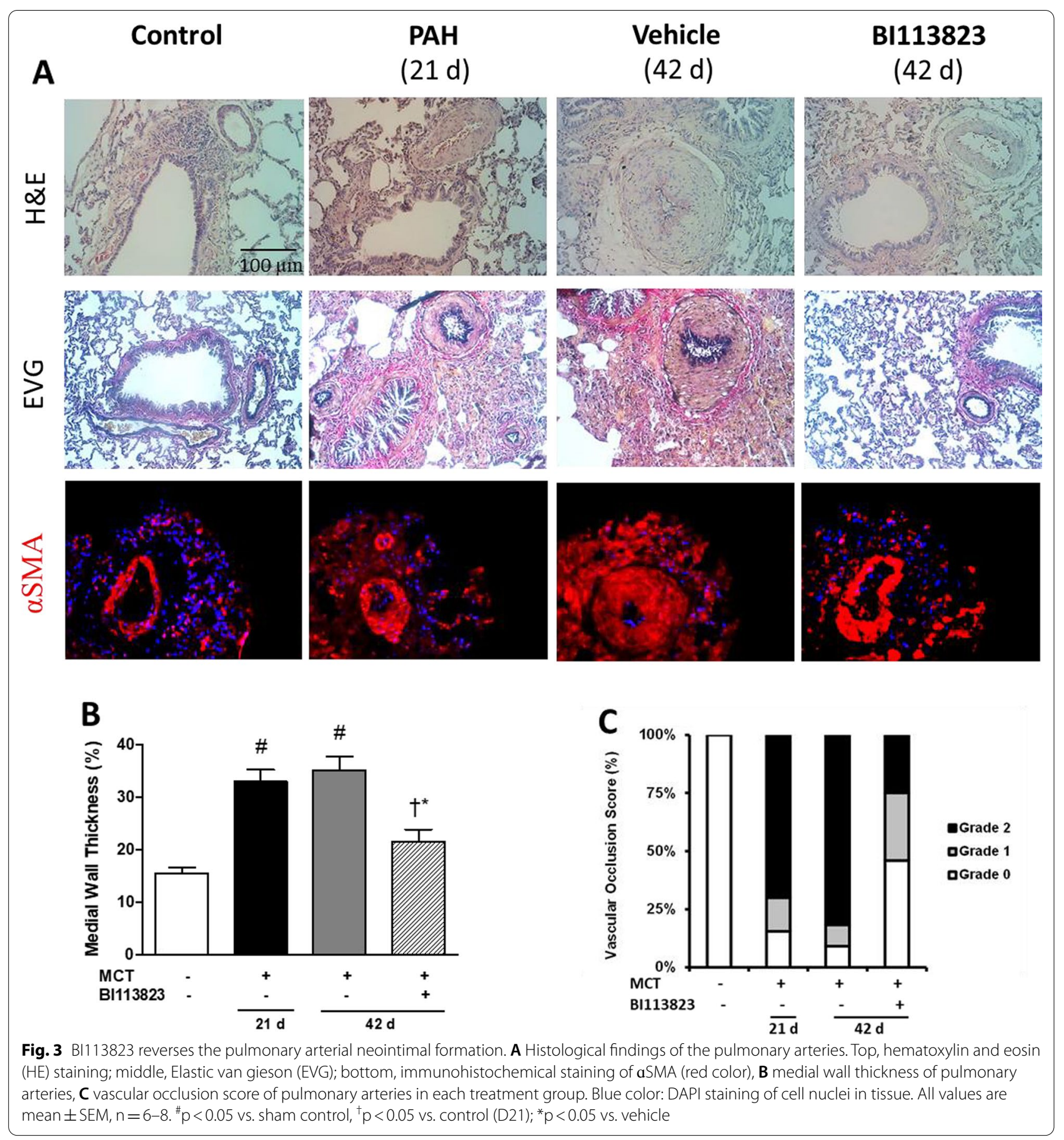

and prevents right heart failure and death. The effects afforded by BI113823 appears to be related to inhibition of macrophage infiltration, and thus subsequently down-regulation of proinflammatory mediators, including cytokines, matrix metalloproteinase proteins, as well as inhibition of ERK and PI3K/Akt signaling pathways.
Reversing advanced PAH and preventing right heart failure and death

In the present study, the rats received two "hits" combination of pneumonectomy and MCT administration developed severe pulmonary hypertension and vascular remodeling that resemble those seen in humans with $\mathrm{PAH}$ $[14,18,19]$. Three weeks following MCT administration 


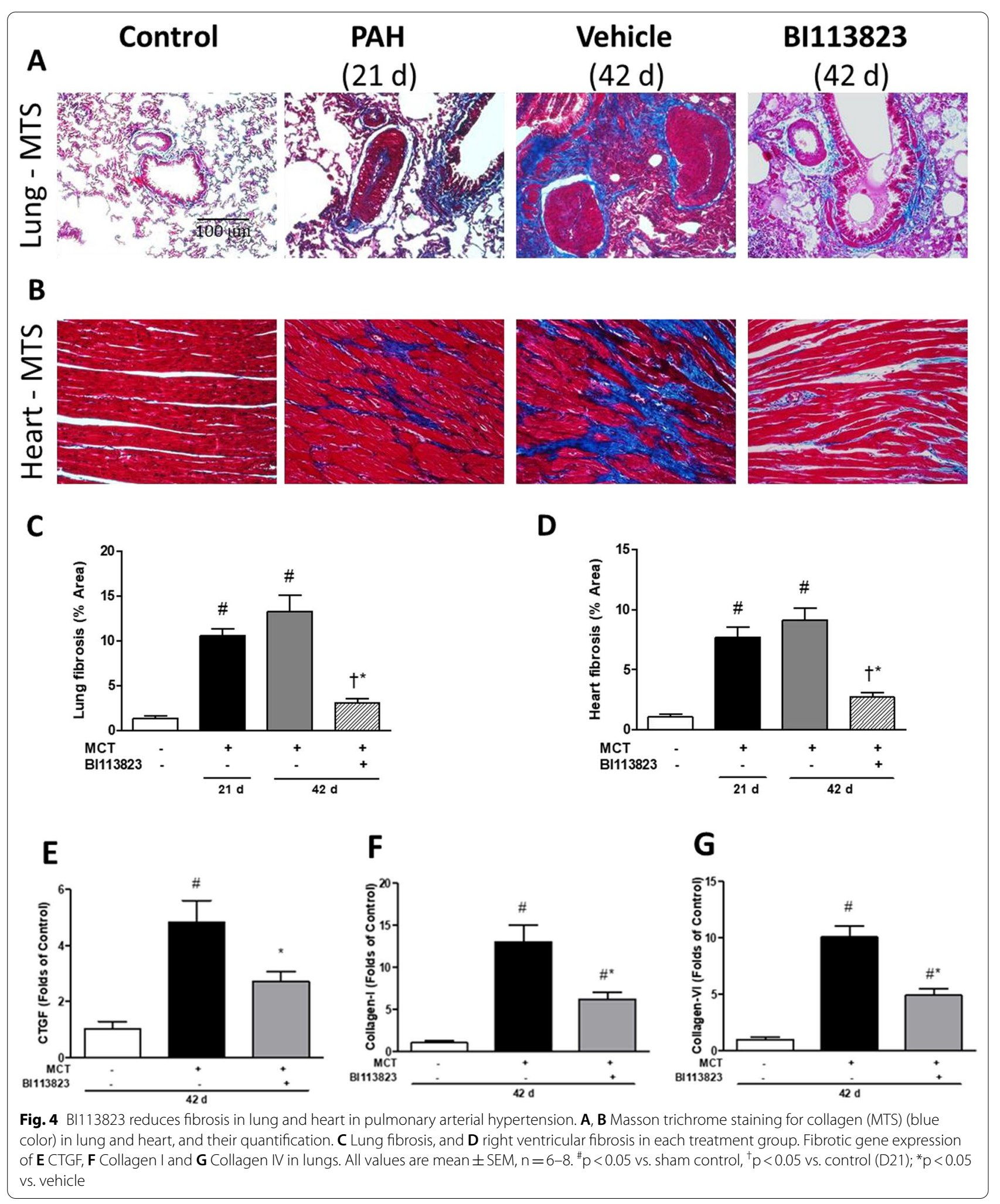


in pneumonectomized rats, pulmonary hypertension and pulmonary vascular neointimal formation were evident. Early treatment with BI113823 (week 1-3 following MCT injection) protected lungs from developing pulmonary arterial hypertension and vascular remodeling [14]. BI113823 treatment (week 4-6 following MCT injection), reversed the progress of vascular remodeling with neointimal formation, lessened pulmonary hypertension and right ventricular hypertrophy, and improved long term survival.

Sustained vasoconstriction and vascular remodeling with neointimal formation are major factors that contribute to the complex pathogenesis of PAH [1, 2]. Vasoconstriction and progressive narrowing of small pulmonary arteries and arterioles result in increased pulmonary vascular resistance for blood flow through the lungs, leading to elevated blood pressure in the pulmonary circulation and right ventricular pressure overload [1, 2, 18]. Kinin B1 receptors mediate strong, endothelium-independent vascular constrictions in arteries following injury, but have no response in normal arteries $[19,22]$. Kinin B1 receptors have been shown to mediate strong contractile responses in pulmonary arteries of piglets with sepsis and in endotoxin-damaged pig coronary arteries, and decrease epicardial diameters in heart transplant patients $[19,22]$. These contractile responses in cardio-pulmonary vascular beds to kinin B1 receptor agonist des-Arg9-BK are mediated by coupling to cyclooxygenases-2 and activation of thromboxane-prostanoid receptors $[19,22]$. Kinin B1 receptors up-regulation in vascular smooth muscle cells can be induced by various mediators, including cytokines, endotoxin, angiotensin II and endothelin-1, and may therefore subsequently increase cardio-pulmonary vascular tone $[11,19,22]$.

In $\mathrm{PAH}$, death generally occurs due to right heart failure $[1,2]$. Kinin B1 receptors are also involved in the pathogenesis of cardiac dysfunction [23, 24]. Upregulation of B1 receptors was seen within hours, days and weeks after myocardial injury $[20,25,26]$. Kinin B1 receptor deletion attenuated diabetic cardiomyopathy with improved systolic and diastolic function in comparison with diabetic control mice [24]. Treatment with BI113823 attenuated postinfarction cardiac hypertrophy and improved cardiac performance following prolonged myocardial infarction in rats [25]. In the present study, treatment with BI113823 rescued preexisting advanced $\mathrm{PAH}$, restored myocardial function, and improved long term survival. Collectively, the protective effects afforded by BI113823 were attributed to regulating pulmonary vascular tone, attenuating cardiovascular remodeling and improving cardiac function.

\section{Macrophages and cardiovascular remodeling in $\mathrm{PAH}$}

Animal experiments and clinical human studies indicate that inflammation contributes to the development of $\mathrm{PAH}$ [2-7]. A prominent pathological feature of $\mathrm{PAH}$ is perivascular accumulation of macrophages $[1,2]$. CD68 positive macrophages are prominent in advanced plexiform lesions observed in experimental and clinical PAH [2-7]. Macrophage accumulation in the aortic wall during angiotensin II infusion in mice is associated with fibrosis, elastin loss, and elevated blood pressure [27]. Activation of macrophages is also closely linked to proliferation of vascular fibroblasts in patients and in experimental models of PAH [28]. Macrophage depletion lowers blood pressure and restores sympathetic nerve adrenergic receptor function in mesenteric arteries of DOCA-salt hypertensive rats [29]. Macrophage depletion also prevents portopulmonary hypertension in an experimental animal model of hepatopulmonary syndrome in rats [30]. Blocking macrophage derived leukotriene B4 also prevents endothelial injury and reverses pulmonary hypertension [4]. These findings demonstrate that perivascular macrophage accumulation plays a key role in pulmonary vascular remodeling and development of PAH [2-7, 27-30].

Kinin B1 receptors play an important role in inflammatory cell activation, and mediate diverse pathological processes by triggering the release of various mediators including cytokines, prostaglandins, leukotrienes, and reactive oxygen species $[9,10]$. Kinins stimulate bovine alveolar macrophages to activate the chemotaxis of neutrophils, monocytes, and eosinophils through $\mathrm{B} 1$ receptor mediated responses [31]. In patients with atheromatous disease, there is high kinin B1 receptor expression, but low kinin B2 receptor expression on foamy macrophages within thickened intimal plaques [15]. In the present study, B1 receptor expression was upregulated in the lung tissues of MCT-challenged pneumonectomized rats in vivo and in LPS treated human monocytes in vitro. Treatment with kinin B1 receptor antagonist BI113823 decreased MCT challenge-induced up-regulation of

\footnotetext{
(See figure on next page.)

Fig. 5 Bl113823 inhibits inflammatory cell recruitment and cytokines production in an experimental model of PAH-induced by monocrotaline injection in pneumonectomized rats. A Inflammatory cell count in bronchoalveolar lavage (BAL), B protein content, C TNF-a, and $\mathbf{D}$ IL-1 $\beta$ in BAL, E TNF-a in plasma, and F Lung MPO activity of each treatment group. Immunohistochemical analysis for $\mathbf{G}$ CD-68 (green color) and proliferating cell nuclear antigen (PCNA) (red color) and their quantification in lung sections from each treatment group. Blue color: DAPI staining of cell nuclei in tissue. All values are mean \pm SEM, $n=6-8$. ${ }^{*} p<0.05$ vs. sham control; ${ }^{\dagger} p<0.05$ vs. control (D21); ${ }^{*} p<0.05$ vs. vehicle
} 


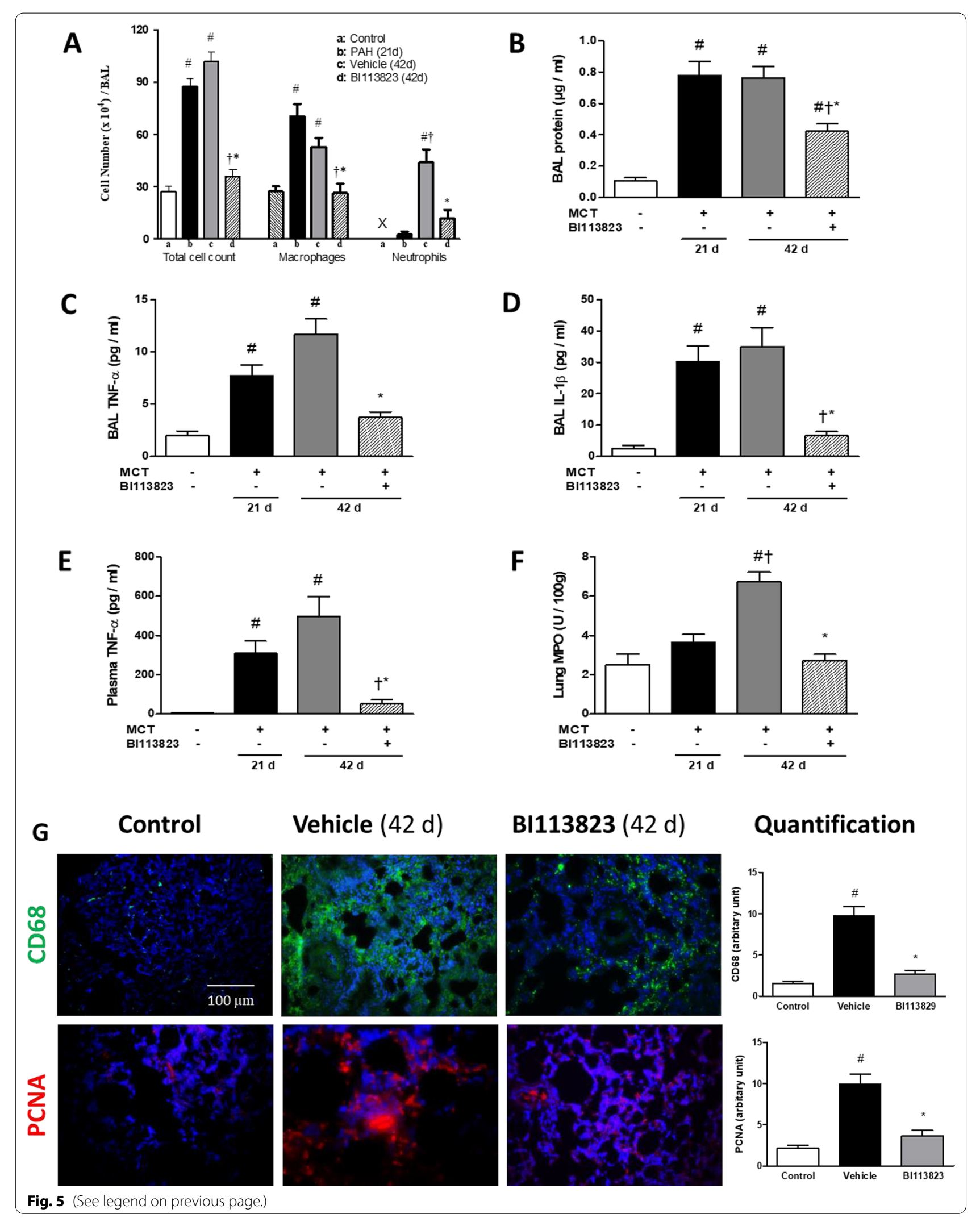




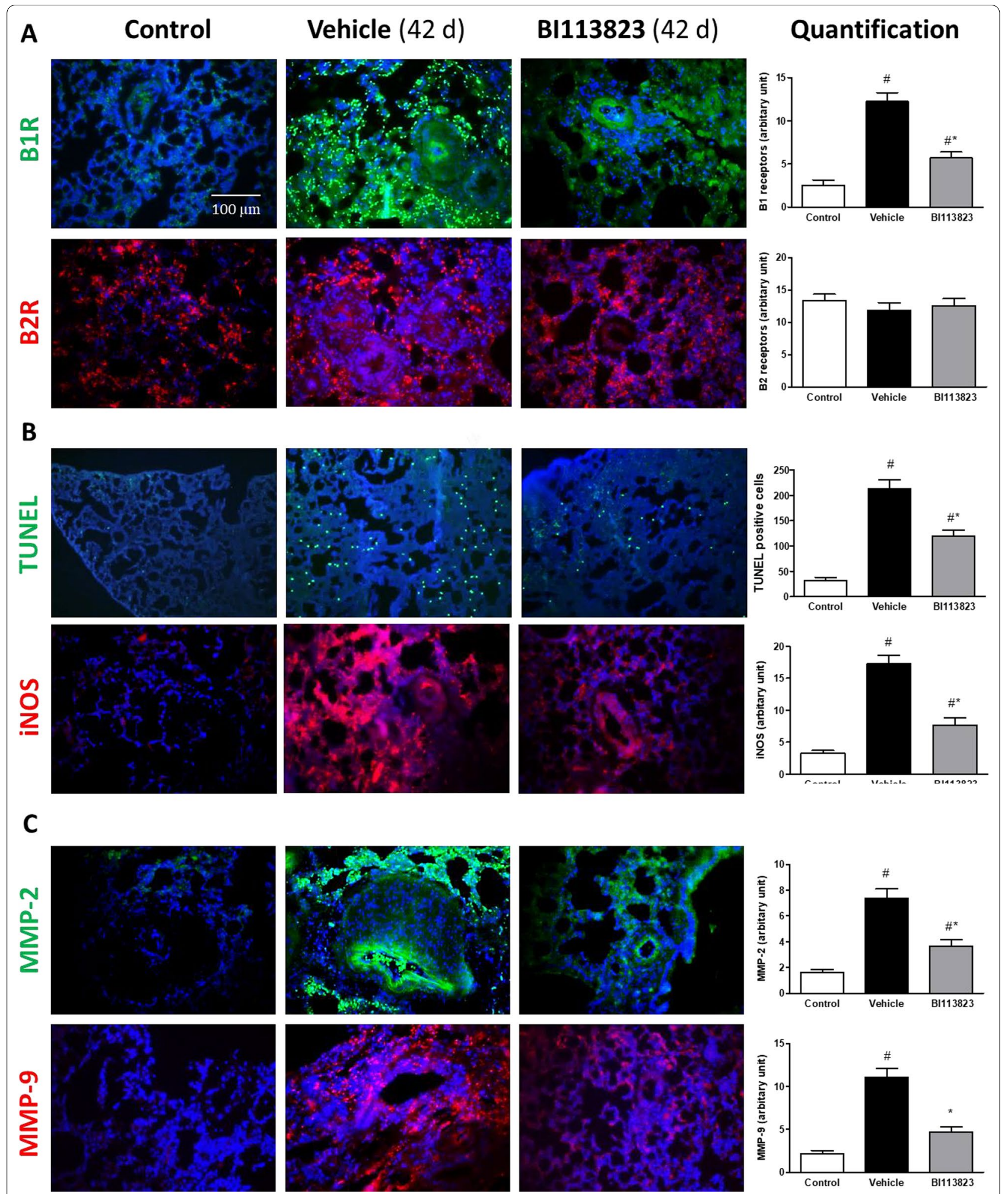

Fig. 6 Immunohistochemical analysis for A kinin B1 (green color) and B2 receptors (red color), B Apoptotic cells (green color) and iNOS (red color) expression and $\mathbf{C}$ matrix metalloproteinase (MMP)-2 (green color) and MMP-9 (red color) in lung sections from each treatment group. Blue color: DAPI staining of cell nuclei in tissue. All values are mean $\pm S E M, n=6 .{ }^{*} p<0.05$ vs. sham control, ${ }^{*} p<0.05$ vs. vehicle 


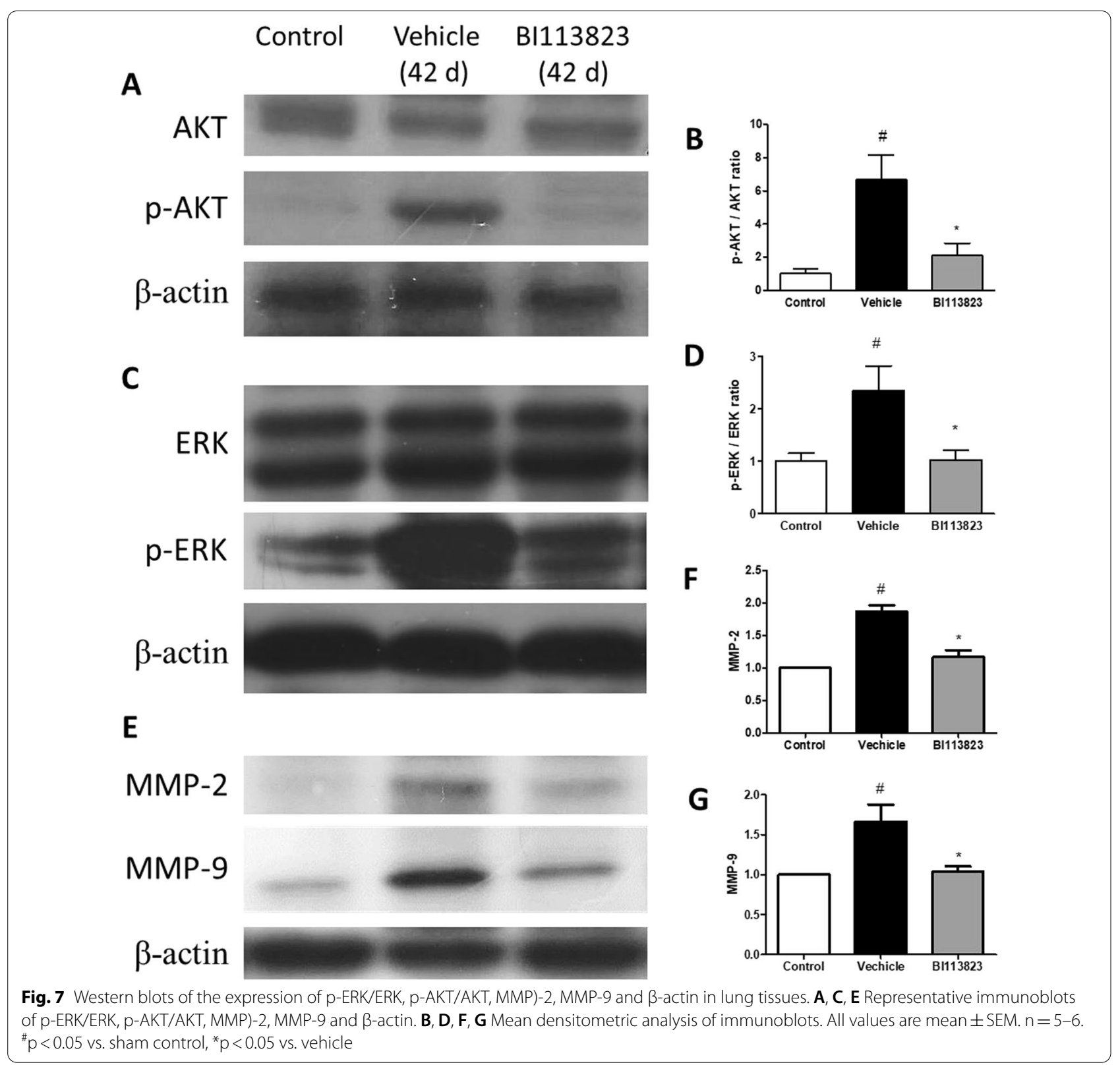

kinin B1 receptors, recruitment of macrophages and neutrophils in the lungs and inhibited TNF- $\alpha$ induced human monocyte migration. There was also a significant reduction of CD-68 positive macrophages into perivascular areas in rats treated with BI113823 compared to vehicle-control animals. Furthermore, the reduction in macrophage infiltration was accompanied by a significant reduction in proinflammatory cytokine TNF- $\alpha$, IL-1 $\beta$ release in bronchoalveolar lavage and plasma, as well as in cultured human monocytes. Cytokines such as TNF- $\alpha$ and IL-1 $\beta$ are major contributing factors in the pathogenesis of PAH $[32,33]$. These findings suggest that inhibition of macrophage recruitment and cytokine production are important contributing factors to the attenuation of pulmonary arterial hypertension and vascular remodeling afforded by $\mathrm{B} 1$ receptor inhibition with BI113823. The reduction of the expression of kinin B1 receptors in BI113823 treated animals may be associated with its effects in inhibition of inflammatory mediators and pathways.

\section{Role of cellular pathways}

The process of pulmonary vascular remodeling and neointimal formation is attributed to pathological 
A

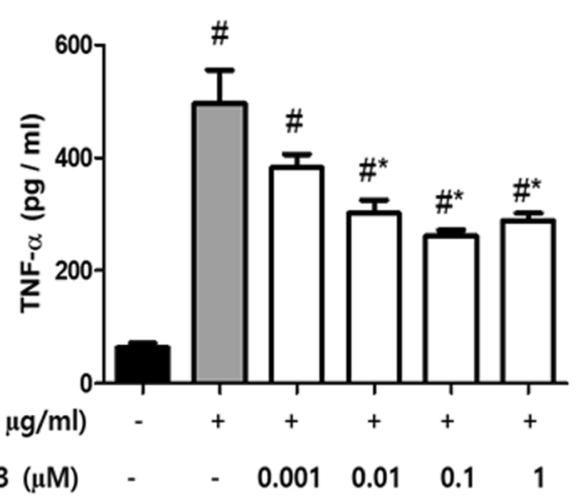

C

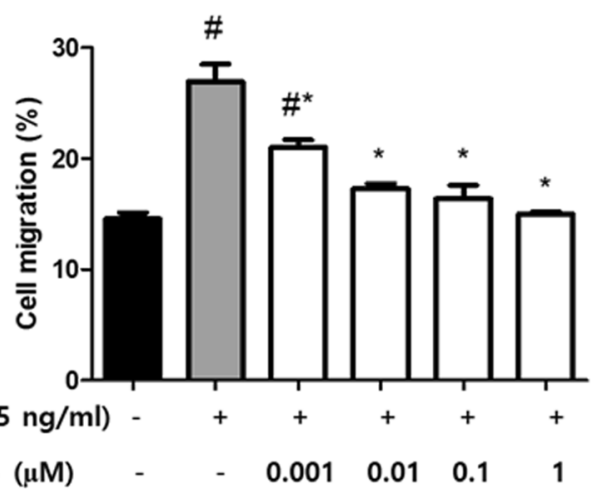

TNF- $\alpha(25 \mathrm{ng} / \mathrm{ml})$

B1113823 $(\mu \mathrm{M})$
B

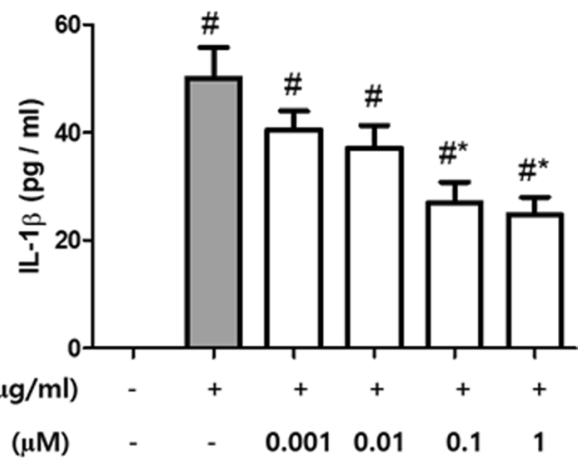

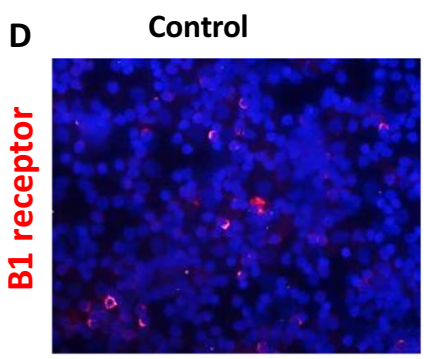
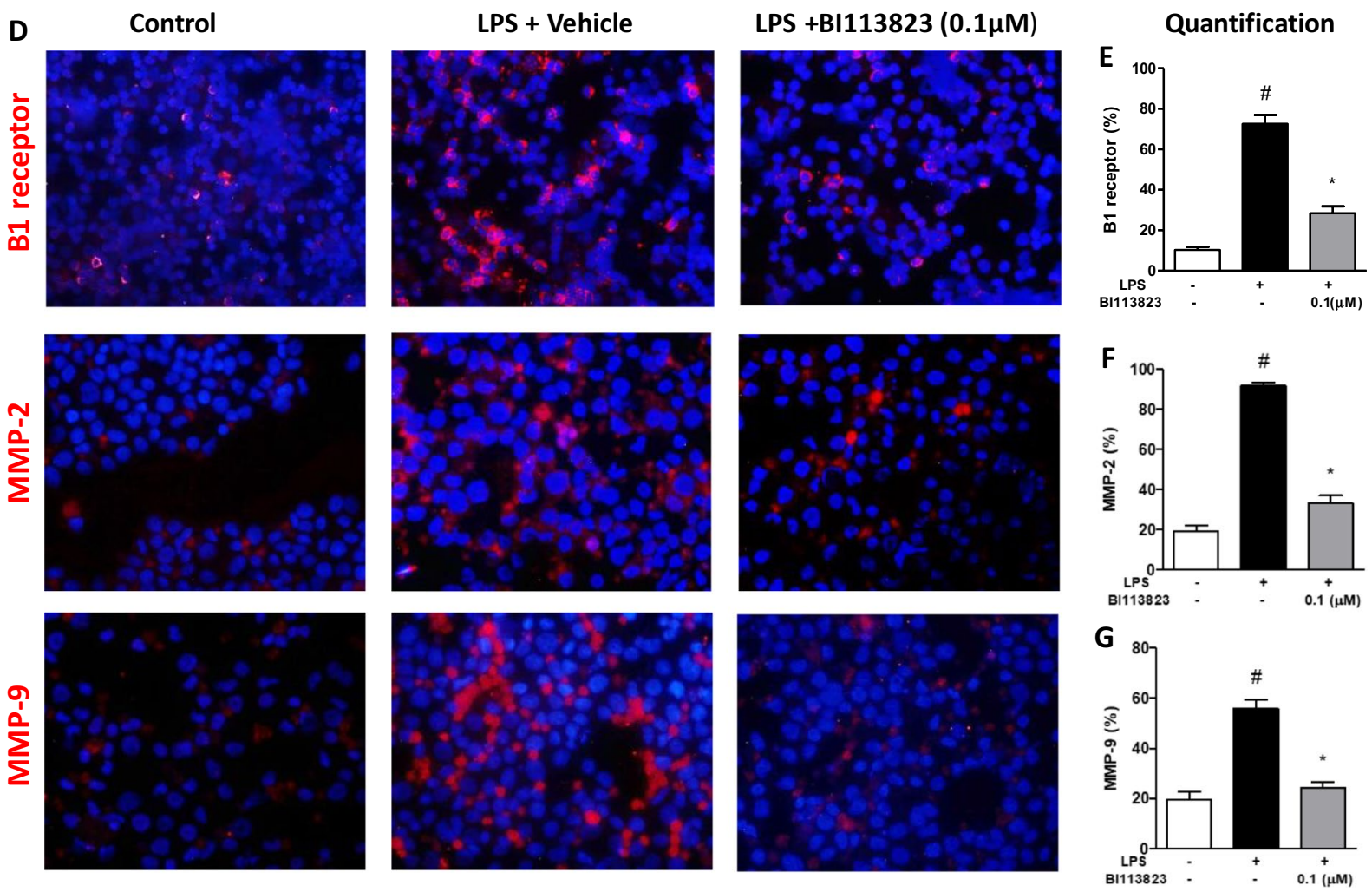

Fig. 8 Effects of kinin B1 receptor antagonist Bl1 13823 on LPS-induced $\mathbf{A}$ TNF- $\alpha$ and $\mathbf{B} \mathrm{IL}-1 \beta$ production, C TNF- $\alpha$-induced monocyte migration, and D-G LPS-induced expression of B1 receptors (red color), MMP-2 (red color) and MMP-9 (red color) in U937 human monocytes. Blue color: DAPI staining of cell nuclei. Data are mean $\pm S E M, n=5-6,{ }^{*} p<0.05$ vs. control, ${ }^{*} p<0.05$ vs. vehicle 
changes to cell signaling pathways in PAH [1-3]. Pulmonary hypertension has been shown to activate cell signaling pathways such as the mitogen-activated protein kinases (MAPKs), and phosphatidylinositol 3-kinase (PI3K)/serine-threonine kinase AKT signaling pathways $[1-3,34]$. AKT and ERK are parallel signaling pathways activated by Growth factors \& Mitogens, both phosphorylates tuberous sclerosis complex 2 (TSC2) to suppress the inhibitory effect of the TSC1-TSC2 complex on mTORC1, thus leading to increased mTORC1 signaling which phosphorylates eukaryotic initiation factor 4E-binding protein (4E-BP) and p70S6K [35].

Both AKT and ERK signaling pathways can be activated by growth factors, such as PDGF in vascular smooth muscle cells, regulating cell cycle progression and cell survival $[35,36]$. The PI3K-Akt and MEK/ERK signaling pathway are also activated rapidly in response to TLR activation in macrophages to regulate the inflammatory stimuli, migration and phagocytosis [37].

The PI3K-Akt and MEK/ERK signaling pathway are involved in cell proliferation, survival, extracellular remodeling and fibrosis which are major features of pulmonary vascular smooth muscle cells associated with PAH [38-40]. AKT is an essential downstream target of PI3K for the remodeling of actin filaments to increase cell migration and for proliferation of VSMCs involved in vascular remodeling $[39,40]$. The MAPKs regulate diverse cellular programs by relaying extracellular signals to intracellular responses [41]. Activation of MAPK promotes cellular growth and proliferation through the phosphorylation and inactivation of pro-apoptotic proteins, and that contributes to the hypoxia-induced PAH-associated pulmonary vascular remodeling [41, 42]. Phosphorylation of ERK1/2 is significantly increased in MCT induced PAH rat model and Inhibition of the ERK1/2 signaling pathway activation prevents pulmonary vascular remodeling, elevated right ventricular pressure and improves right ventricular hypertrophy in experimental animal models of PAH model [43, 44]. Proinflammatory mediators such as TNF- $\alpha$ and interleukins induce kinin $\mathrm{B} 1$ receptor upregulation by activate intracellular MAPK/NF- $\mathrm{KB}$ and their related signal pathways including iNOS and PI3K/AKT signaling pathways [12, 45]. Kinin B1 receptor stimulation triggers synthesis and secretion of matrix metalloproteases (MMPs), and subsequent phosphorylation of ERK1/2 and PI3K/AKT [44]. The MMPs play a crucial role in tissue remodeling through the regulation of extracellular matrix degradation, cell migration, differentiation, and cell proliferation [46]. In the present study, kinin B1 receptor blockade with BI113823 significantly reduced the expression of matrix metalloproteinase (MMP)-2, MMP-9 and iNOS, and inhibited the phosphorylation of ERK1/2 and AKT, and compared to measurements in vehicle-treated rats. In human monocytes, BI113823 reduced cytokine production, inhibited monocyte migration, and down-regulated the expression of MMP-2 and MMP-9. Cytokines, including TNF- $\alpha$ and IL-1, have been shown to regulate the production of macrophage-derived MMPs in arthrosclerosis lesions [47].

It has been reported that compounds (e.g., simvastatin) reduces pulmonary hypertension by inducing apoptosis of neointimal smooth muscle cells [19]. However, our study show that BI113823 attenuates growth factors and hypoxia stimulated pulmonary artery smooth muscle cell migration and proliferation [14], does not induce apoptosis in this study.

Kinin peptides enhance inflammatory and oxidative responses promoting apoptosis in a Parkinson's disease cellular model [48]. In a rat model of sepsis via CLP, BI113823 reduced inflammation and cell apoptosis in liver tissue [13]. In this study, BI113823 treatment significantly reduced inflammatory cell infiltration, inflammatory markers like TNF $\alpha$, IL-1 $\beta, \mathrm{B} 1 \mathrm{R}, \mathrm{MPO}$, as well as apoptotic cells in lung tissue which suggest reduced tissue inflammatory injury.

Collectively, the findings of the present study suggest that inhibition of macrophage recruitment, down regulation of cytokine production and MMPs, as well as downstream pathways by BI113823 may contributed to the reversal of the progression of pulmonary hypertension and vascular remodeling.

\section{Conclusion and perspectives}

We conclude that BI113823 reverses the progression of vascular remodeling, lessens pulmonary arterial hypertension, and prevents right heart failure and death. The protective effects afforded by BI113823 are mediated through inhibition macrophage infiltration, and subsequently down-regulation of proinflammatory mediators. This regimen offers a unique novel approach for antiinflammatory and remodeling therapy in progressed pulmonary hypertension.

\section{Abbreviations \\ PAH: Pulmonary arterial hypertension; mPAP: Mean pulmonary arterial pres- sure; RVSP: Right ventricular systolic blood pressure; PAP: Pulmonary arterial pressure; PCNA: Proliferating cell nuclear antigen; MMP: Matrix metallopro- teinase; MIP-1a: Macrophage inflammatory protein-1 alpha; MCT: Monocro- taline; BAL: Bronchoalveolar lavage; TNF-a: Tumor necrosis factor alpha; MPO: Myeloperoxidase; a-SMA: a-Smooth muscle actin; MAPKs: Mitogen-activated protein kinases; PI3K: Phosphatidylinositol 3-kinase.}

\section{Acknowledgements}

Not applicable.

Authors' contributions

DW, PM, and DRR conceived the study concept and experimental design. PM, DRR, and HF performed experiments, collected data and performed statistical 
analysis. $H C, W D, D L, A P$ and $H D$ provided intellectual input and supervision. DW and DRR drafted the manuscript. All authors read and approved the final manuscript.

\section{Funding}

This work was supported in part by National Research Foundation of Korea (NRF) grants funded by the Korean government (MSIP) (2016R1A2B4013744 and 2019R1A2C1006194).

\section{Availability of data and materials}

The datasets used and /or analyzed during the current study are available from the corresponding author on reasonable request.

\section{Declarations}

\section{Ethics approval}

All procedures were performed according to the protocols approved by Institutional Animal Care and Use Committee (IACUC) at Chonbuk National University, South Korea.

\section{Consent for publication}

Not applicable.

\section{Competing interests}

D.W. was a former employee (1996-1999) and consultant of Bl and has continued to collaborate with Boehringer Ingelheim. A.P. and H.D. are employees of Boehringer Ingelheim. This does not alter the authors' adherence to all the Journal policies on sharing data and materials. Other co-authors: None.

\section{Author details}

'Department of Bio-Nanotechnology and Bio-Convergence Engineering, Chonbuk National University, Jeonju, South Korea. ${ }^{2}$ Department of Neurosurgery, the First Affiliated Hospital of Nanjing Medical University, Nanjing, China. ${ }^{3}$ Research Beyond Borders, Boehringer Ingelheim Pharma GmbH \& Co. KG, Biberach, Germany. ${ }^{4}$ Department of Research, Mount Sinai Medical Center, Miami Beach, FL, USA.

Received: 21 May 2021 Accepted: 19 October 2021 Published online: 30 October 2021

\section{References}

1. Stenmark KR, Mecham RP. Cellular and molecular mechanisms of pulmonary vascular remodeling. Annu Rev Physiol. 1997;59:89-144.

2. Meloche J, Renard S, Provencher S, Bonnet S. Anti-inflammatory and immunosuppressive agents in PAH. Handb Exp Pharmacol. 2013;218:43776. https://doi.org/10.1007/978-3-642-38664-0_18.

3. El Chami H, Hassoun PM. Immune and inflammatory mechanisms in pulmonary arterial hypertension. Prog Cardiovasc Dis. 2012;55(2):218-28. https://doi.org/10.1016/j.pcad.2012.07.006.

4. Tian W, Jiang X, Tamosiuniene R, Sung YK, Qian J, Dhillon G, Gera L, Farkas L, Rabinovitch M, Zamanian RT, Inayathullah M, Fridlib M, Rajadas J, Peters-Golden M, Voelkel NF, Nicolls MR. Blocking macrophage leukotriene b4 prevents endothelial injury and reverses pulmonary hypertension. Sci Transl Med. 2013. https://doi.org/10.1126/scitranslmed.3006674.

5. Groth A, Vrugt B, Brock M, Speich R, Ulrich S, Huber LC. Inflammatory cytokines in pulmonary hypertension. Respir Res. 2014;15:47.

6. Cool CD, Kennedy D, Voelkel NF, Tuder RM. Pathogenesis and evolution of plexiform lesions in pulmonary hypertension associated with scleroderma and human immunodeficiency virus infection. Hum Pathol. 1997;28:434-42.

7. Stacher E, Graham BB, Hunt JM, Gandjeva A, Groshong SD, McLaughlin W, Jessup M, Grizzle WE, Aldred MA, Cool CD, Tuder RM. Modern age pathology of pulmonary arterial hypertension. Am J Respir Crit Care Med. 2012;186:261-72.

8. Leeb-Lundberg LM, Marceau F, Müller-Esterl W, Pettibone DJ, Zuraw BL. International union of pharmacology. XLV. Classification of the kinin receptor family: from molecular mechanisms to pathophysiological consequences. Pharmacol Rev. 2005;57(1):27-77.
9. Calixto JB, Medeiros R, Fernandes ES, Ferreira J, Cabrini DA, Campos MM. Kinin B1 receptors: key G-protein-coupled receptors and their role in inflammatory and painful processes. Br J Pharmacol. 2004;143(7):803-18.

10. Böckmann S, Paegelow I. Kinins and kinin receptors: importance for the activation of leukocytes. J Leukoc Biol. 2000;68(5):587-92.

11. More AS, Kim HM, Khang G, Hildebrandt T, Bernlöhr C, Doods H, Vanhoutte PM, Wu D. Des-Arg9-bradykinin causes kinin B1 receptor mediated endothelium-independent contractions in endotoxin-treated porcine coronary arteries. Pharmacol Res. 2014;90C:18-24.

12. Nasseri S, Gurusamy M, Jung B, Lee D, Khang G, Doods H, Wu D. Kinin B1 receptor antagonist Bl1 13823 reduces acute lung injury. Crit Care Med. 2015;43(11):e499-507. https://doi.org/10.1097/CCM.0000000000001268.

13. Murugesan $P$, Jung $B$, Lee D, Khang G, Doods H, Wu D. Kinin B1 receptor inhibition with Bl113823 reduces inflammatory response, mitigates organ injury, and improves survival among rats with severe sepsis. I Infect Dis. 2016;213(4):532-40. https://doi.org/10.1093/infdis/jiv426.

14. Murugesan P, Hildebrandt T, Bernlöhr C, Lee D, Khang G, Doods H, Wu D. Inhibition of kinin B1 receptors attenuates pulmonary hypertension and vascular remodeling. Hypertension. 2015;66(4):906-12. https://doi.org/10. 1161/HYPERTENSIONAHA.115.05338.

15. Raidoo DM, Ramsaroop R, Naidoo S, Müller-Esterl W, Bhoola KD. Kinin receptors in human vascular tissue: their role in atheromatous disease. Immunopharmacology. 1997;36(2-3):153-60.

16. Faussner A, Bathon JM, Proud D. Comparison of the responses of B1 and B2 kinin receptors to agonist stimulation. Immunopharmacology. 1999;45(1-3):13-20.

17. Stenmark KR, Meyrick B, Galie N, Mooi WJ, McMurtry IF. Animal models of pulmonary arterial hypertension: the hope for etiological discovery and pharmacological cure. Am J Physiol Lung Cell Mol Physiol. 2009;297(6):L1013-32. https://doi.org/10.1152/ajplung.00217.2009.

18. Nishimura T, Vaszar LT, Faul JL, Zhao G, Berry GJ, Shi L, Qiu D, Benson G, Pearl RG, Kao PN. Simvastatin rescues rats from fatal pulmonary hypertension by inducing apoptosis of neointimal smooth muscle cells. Circulation. 2003;108(13):1640-5.

19. Faul JL, Nishimura T, Berry GJ, Benson GV, Pearl RG, Kao PN. Triptolide attenuates pulmonary arterial hypertension and neointimal formation in rats. Am J Respir Crit Care Med. 2000;162:2252-8.

20. Ambade AS, Jung B, Lee D, Doods H, Wu D. Triple-tyrosine kinase inhibition attenuates pulmonary arterial hypertension and neointimal formation. Transl Res. 2019:203:15-30.

21. Wu D, Lin X, Bernloehr C, Hildebrandt T, Doods H. Effects of a novel bradykinin B1 receptor antagonist and angiotensin II receptor blockade on experimental myocardial infarction in rats. PLoS ONE. 2012;7(12):e51151.

22. Whitehurst RM, Laskey R, Goldberg RN, Herbert D, Van Breemen C. Influence of group $B$ streptococci on piglet pulmonary artery response to bradykinin. J Appl Physiol. 1999;86:61-5.

23. Aptecar E, Lecorvoisier P, Teiger E, Garot P, Dupouy P, Sediame S, Vermes E, Loisance D, Hittinger L, Dubois-Rande JL, Montagne O. Coronary vasomotor response to the selective B1-kinin-receptor agonist Des-Arg9bradykinin in humans. J Heart Lung Transplant. 2006;25:187-94.

24. Westermann D, Walther T, Savvatis K, Escher F, Sobirey M, Riad A, Bader M, Schultheiss HP, Tschöpe C. Gene deletion of the kinin receptor B1 attenuates cardiac inflammation and fibrosis during the development of experimental diabetic cardiomyopathy. Diabetes. 2009;58(6):1373-81.

25. Lin X, Bernloehr C, Hildebrandt T, Stadler FJ, Doods H, Wu D. Kinin B receptor blockade and ACE inhibition attenuate cardiac postinfarction remodeling and heart failure in rats. Toxicol Appl Pharmacol. 2016. https://doi.org/10.1016/j.taap.2016.06.005.

26. Tschöpe C, Heringer-Walther $S$, Walther T. Regulation of the kinin receptors after induction of myocardial infarction: a mini-review. Braz J Med Biol Res. 2000;33(6):701-8.

27. Thang LV, Demel SL, Crawford R, Kaminski NE, Swain GM, van Rooijen N, Galligan JJ. Macrophage depletion lowers blood pressure and restores sympathetic nerve a2-adrenergic receptor function in mesenteric arteries of DOCA-salt hypertensive rats. Am J Physiol Heart Circ Physiol. 2015. https://doi.org/10.1152/ajpheart.00283.2015.

28. Li M, Riddle SR, Frid MG, El Kasmi KC, McKinsey TA, Sokol RJ, Strassheim D, Meyrick B, Yeager ME, Flockton AR, McKeon BA, Lemon DD, Horn TR, Anwar A, Barajas C, Stenmark KR. Emergence of fibroblasts with a proinflammatory epigenetically altered phenotype in severe hypoxic 
pulmonary hypertension. J Immunol. 2011;187(5):2711-22. https://doi. org/10.4049/jimmunol.1100479.

29. Moore JP, Vinh A, Tuck KL, Sakkal S, Krishnan SM, Chan CT, Lieu M, Samuel CS, Diep H, Kemp-Harper BK, Tare M, Ricardo SD, GuzikTJ, Sobey CG, Drummond GR. M2 macrophage accumulation in the aortic wall during angiotensin II infusion in mice is associated with fibrosis, elastin loss, and elevated blood pressure. Am J Physiol Heart Circ Physiol. 2015;309(5):H906-17. https://doi.org/10.1152/ajpheart.00821.2014.

30. Thenappan T, Goel A, Marsboom G, Fang YH, Toth PT, Zhang HJ, Kajimoto H, Hong Z, Paul J, Wietholt C, Pogoriler J, Piao L, Rehman J, Archer SL. A central role for $\mathrm{CD68}(+)$ macrophages in hepatopulmonary syndrome. Reversal by macrophage depletion. Am J Respir Crit Care Med. 2011;183(8):1080-91. https://doi.org/10.1164/rccm.201008-13030C

31. Sato E, Koyama S, Nomura H, Kubo K, Sekiguchi M. Bradykinin stimulates alveolar macrophages to release neutrophil, monocyte, and eosinophil chemotactic activity. J Immunol. 1996;157(7):3122-9.

32. Stow JL, Low PC, Offenhäuser C, Sangermani D. Cytokine secretion in macrophages and other cells: pathways and mediators. Immunobiology. 2009;214:601-12.

33. Dorfmüller P, Zarka V, Durand-Gasselin I, Monti G, Balabanian K, Garcia G, Capron F, Coulomb-Lherminé A, Marfaing-Koka A, Simonneau G, Emilie D, Humbert M. Chemokine RANTES in severe pulmonary arterial hypertension. Am J Respir Crit Care Med. 2002;165:534-9.

34. Kiss T, Kovacs K, Komocsi A, Tornyos A, Zalan P, Sumegi B, Gallyas F Jr, Kovacs K. Novel mechanisms of sildenafil in pulmonary hypertension involving cytokines/chemokines, MAP kinases and Akt. PLOS ONE. 2014:9(8):e104890. https://doi.org/10.1371/journal.pone.0104890.

35. Bahrami-B F, Ataie-Kachoie P, Pourgholami MH, Mo DL. p70 Ribosomal protein S6 kinase (Rps6kb1): an update. J Clin Pathol. 2014;67(12):101925. https://doi.org/10.1136/jclinpath-2014-202560.

36. Hayashi K, Takahashi M, Kimura K, Nishida W, Saga H, Sobue K. Changes in the balance of phosphoinositide 3-kinase/protein kinase B (Akt) and the mitogen-activated protein kinases (ERK/P38MAPK) determine a phenotype of visceral and vascular smooth muscle cells. J Cell Biol. 1999;145(4):727-40.

37. McGuire VA, Gray A, Monk CE, Santos SG, Lee K, Aubareda A, Crowe J, Ronkina N, Schwermann J, Batty JH, Leslie NR, Dean JLE, O'Keefe SJ, Boothby M, Gaestel M, Arthur JSC. Cross talk between the Akt and p38a pathways in macrophages downstream of Toll-like receptor signaling. Mol Cell Biol. 2013;33(21):4152-65. https://doi.org/10.1128/MCB. 01691-12.

38. Di R, Yang Z, Xu P, Xu Y. Silencing PDK1 limits hypoxia-induced pulmonary arterial hypertension in mice via the Akt/p70S6K signaling pathway. Exp Ther Med. 2019;18(1):699-704. https://doi.org/10.3892/etm.2019.7627.

39. Qian Y, Corum L, Meng Q, Blenis J, Zheng JZ, Shi X, Flynn DC, Jiang BH. PI3K induced actin filament remodeling through Akt and p70S6K1: implication of essential role in cell migration. Am J Physiol Cell Physiol. 2004;286(1):C153-63.

40. Kim TJ, Yun YP. Antiproliferative activity of NQ304, a synthetic 1,4-naphthoquinone, is mediated via the suppressions of the PI3K/Akt and ERK1/2 signaling pathways in PDGF-BB-stimulated vascular smooth muscle cells. Vasc Pharmacol. 2007;46(1):43-51.

41. Muslin AJ. MAPK signalling in cardiovascular health and disease: molecular mechanisms and therapeutic targets. Clin Sci (Lond). 2008;115(7):20318. https://doi.org/10.1042/CS20070430.

42. Yu X, LiT, Liu X, Yu H, Hao Z, Chen Y, Zhang C, Liu Y, Li Q, Mao M, Zhu D. Modulation of pulmonary vascular remodeling in hypoxia: role of 15-LOX2/15-HETE-MAPKs pathway. Cell Physiol Biochem. 2015;35(6):2079-97. https://doi.org/10.1159/000374015.

43. Klein M, Schermuly RT, Ellinghaus P, Milting H, Riedl B, Nikolova S, Pullamsetti SS, Weissmann N, Dony E, Savai R, Ghofrani HA, Grimminger F, Busch $A E$, Schäfer S. Combined tyrosine and serine/threonine kinase inhibition by sorafenib prevents progression of experimental pulmonary hypertension and myocardial remodeling. Circulation. 2008;118(20):2081-90. https://doi.org/10.1161/CIRCULATIONAHA.108.779751.

44. Moreno-Vinasco L, Gomberg-Maitland M, Maitland ML, Desai AA, Singleton PA, Sammani S, Sam L, Liu Y, Husain AN, Lang RM, Ratain MJ, Lussier YA, Garcia JG. Genomic assessment of a multikinase inhibitor, sorafenib, in a rodent model of pulmonary hypertension. Physiol Genomics. 2008;33(2):278-91. https://doi.org/10.1152/physiolgenomics.00169.2007.

45. Zhang Y, Cardell LO, Edvinsson L, Xu CB. MAPK/NF-KB-dependent upregulation of kinin receptors mediates airway hyperreactivity: a new perspective for the treatment. Pharmacol Res. 2013;71:9-18. https://doi. org/10.1016/j.phrs.2013.02.004.

46. Matus CE, Ehrenfeld P, Pavicic F, González CB, Concha M, Bhoola KD, Burgos RA, Figueroa CD. Activation of the human keratinocyte B1 bradykinin receptor induces expression and secretion of metalloproteases 2 and 9 by transactivation of EGFR. Exp Dermatol. 2016. https://doi.org/10.1111/ exd.13038.

47. Yamada S, Koike T, Nakagawa T, Kuniyoshi N, Ying Y, Itabe H, Yamashita A, Asada Y, Shiomi M. Morphological features of coronary plaques in WHHLMI rabbits (Oryctolagus cuniculus), an animal model for familial hypercholesterolemia. Exp Anim. 2017;66(2):145-57.

48. Niewiarowska-Sendo A, Kozik A, Guevara-Lora I. Kinin peptides enhance inflammatory and oxidative responses promoting apoptosis in a Parkinson's disease cellular model. Mediat Inflamm. 2016;2016:4567343.

\section{Publisher's Note}

Springer Nature remains neutral with regard to jurisdictional claims in published maps and institutional affiliations.
Ready to submit your research? Choose BMC and benefit from:

- fast, convenient online submission

- thorough peer review by experienced researchers in your field

- rapid publication on acceptance

- support for research data, including large and complex data types

- gold Open Access which fosters wider collaboration and increased citations

- maximum visibility for your research: over $100 \mathrm{M}$ website views per year

At BMC, research is always in progress.

Learn more biomedcentral.com/submissions 